\title{
Commodity Flows, Diaspora Networking, and Contested Agency in the Eastern Indian Ocean c. $1000-1500$
}

\author{
Kenneth R. Hall
}

\begin{abstract}
Recent revisionist approaches to early pre-1500 eastern Indian Ocean history draw from and cross-reference epigraphic, archaeological, art historical, literary, cultural, textual, shipwreck, and a variety of other primary and secondary sources as these document the evolution of Southeast Asia from roughly 300 to 1500, before significant European regional presence became a factor. This study's focus is the transitional importance of c. 1000-1500 Indian Ocean international maritime trade and transit from the South Asian shorelines of the Bay of Bengal to the South China and Java Seas, which is conceived to have temporarily produced an inclusive eastern Indian Ocean zone of contact. In this then 'borderless' region there were a variety of meaningful contacts and material, cultural, and knowledge transfers that resulted in synthesis of Indian, Chinese, Middle Eastern, and Southeast Asian cultures and populations made possible by enhanced international maritime trade connections before European presence became a factor, a period often dated from the fall of Melaka to the Portuguese in 1511.
\end{abstract}

KEYWORDS: Indian Ocean, history, maritime trade, commodities, Southeast Asia

\section{INTRODUCTION}

$\mathrm{R}$ ECENT HISTORICAL STUDIES HaVE asserted Southeast Asia agency in the pre1500 era, in contrast to prior histories that have advocated Southeast Asia's cultural if not economic and political dependency on India, China, and the Middle East. In this older view Southeast Asians modeled their civilizations on their more 'advanced' neighbors. New 'borderless' approaches have focused on Southeast Asia's connectivity rather than dependency in challenging past Indian Ocean historiography. Herein regional political hegemony over early water transit in the eastern Indian Ocean region is now conceived as less a factor than the networks of multiple maritime trading and religious diaspora that shared a variety of ship, coastal, and port space (Mukherjee 2011, 2014; Blackburn 2015). 


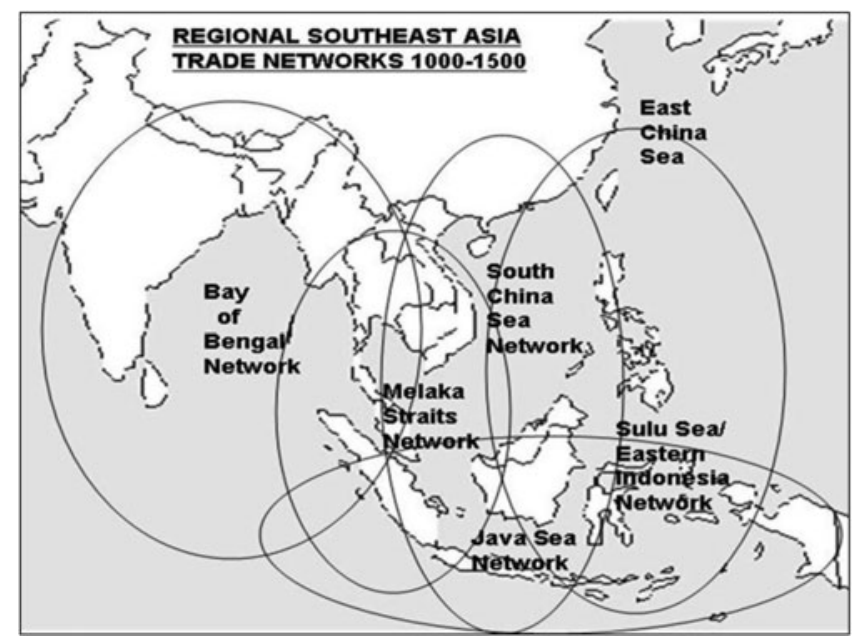

Map 1: Extended eastern Indian Ocean activity zones

Against previous scholarship that was prejudicial to China, the Middle East, and South Asia-based agencies and regional spheres of influence, newly available shipwreck archaeological recoveries in the Southeast Asia maritime region have especially allowed the re-reading of epigraphic and textual sources to better detail the Bay of Bengal, Straits of Melaka, and Java and South China Seas as extended 'borderless' but highly networked extended eastern Indian Ocean passageways between South Asia and China. These multi-centered transit zones included the Bay of Bengal southern, central, and northeast South Asia coastlines; modern-day Myanmar, the Malay Peninsula, and Sri Lanka; the Straits of Melaka region linking Singapore, Sumatra, and north and east coast Java; the overlapping Java Sea eastern Indonesian archipelago and South China Sea regions that included the Vietnam and west and south Borneo coastlines, and southern China, with ongoing eastern links to the Sulu Sea region via the Philippines (Acre, Creese, and Griffiths 2011; Miksic 2013; Schottenhammer and Ptak, eds. 2006) (See Map 1).

Multidisciplinary revisionists address the flow of various contemporary material objects, spices, silk, cotton textiles, coinage, as well as Chinese and Southeast Asian ceramics and Middle Eastern glassware through South Asia and Southeast Asia to China via overland and maritime passageways, and iron to Java and other Indonesian archipelago regions that were iron deficient (Green 2000, 2007: 200; Bielenstein 2005; Wade 2009). As examples, eastern Indonesian archipelago island societies still use c. 1400 South Asia heirloom cotton textiles imported from the Gujarat, south India, Sri Lanka, and the upper Bay of Bengal in regional rituals (Barnes 1989). The mid fourteenth century account of the Middle East sojourner Ibn Battuta provides detailed accounting of these and other commodities in transit and their destinations (Gibb 1929). The contemporary Java Nagarakertagama court chronicle defined the eastern Indian Ocean 
regions with which Java regularly traded: Nusantara was the physical space where Java's monarchs were said to have had direct political interests, but without sovereign control; Desantara, or the "other countries", were even more distant and lay beyond the conceptual trading core. Many of these 'countries' were polities with which Java's monarchs had diplomatic and cultural exchanges as reported in the following Nagarakertagama passage:

“....The above [inclusive Nusantara] are the various regions protected by His Majesty; On the other hand, the Siamese of Ayutthaya and also of Dharmanagari [Nakhon Si Thammarat on the central Malay Peninsula], Marutma [Martaban, Burma/Myanmar, a lower Burma cultural and commercial center], Rajapura [Ratburi, southwest of modern Bangkok], as well as Singhanagari [Singhaburi, north of Ayutthaya on the Chaophraya river], Champa [south and central Vietnam], Cambodia, and Yawana [northern Vietnam] are always friends." (Robson 1995: 34)

A 1,200-year-old salvaged wooden vessel from the western edge of the Java Sea, known as the Belitung wreck (since it sank in Indonesian waters off the coast of Belitung Island), carried over 60,000 pieces of China's Tang dynasty-era ceramics, in addition to notable gold and silver artifacts that are partially represented in a Singapore National Museum display. One inscribed ceramic bowl provides the approximate time of the shipwreck: "the 16th day of the seventh month of the second year of the Baoli reign" (826 CE), which is thought to mark the date that the bowl was fired. The ship's cargo included numbers of these distinctive brown and straw-colored glazed ceramic 'tea bowls' - otherwise named after the Changsha kilns in China's Hunan province where they were produced for broadly based (as opposed to exclusively aristocratic) consumption (Henderson 1999, 2002; Krahl 2010).

The partially recovered Arab dhow vessel, sixty feet long, has a raked prow and stern likely built of African or Indian wood and was fitted with a single square sail. Notably the ship was not held together by dowels, as was the norm among contemporary Chinese and Southeast Asia-built ocean-going craft, but instead its planks were sewn together using coconut-husk fiber cord (Flecker 2001, 2002; Miksic 2009; Krahl et al. 2010). In sum, the variety of cargo indicates that the vessel was transiting via the Straits of Melaka/Java Sea/South China Sea passageway to and from Baghdad carrying a variety of Indian Ocean products such as fine textiles, pearls, coral, and aromatic woods. Its cargo did not contain precious metals (notably much in demand silver), as China's port masters at that time guaranteed that China would not be drained of its precious metals. Thus, the mass 'factory-like production' of ceramics by five different China kilns for the export trade was an intentional state-coordinated enterprise. At that time transporting volumes of ceramics overland to the West via the Central Asia passage on camels or horseback was not suitably efficient. China's 


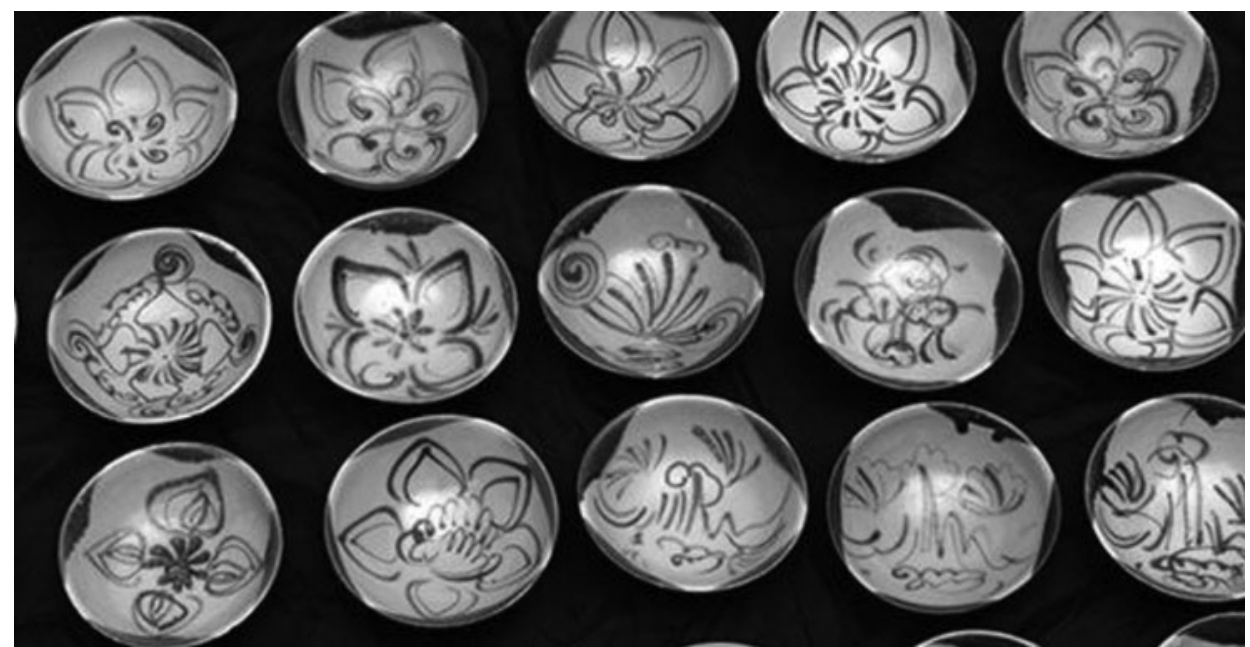

Figure 1. Tang Shipwreck Chinese Ceramics c. 830, Singapore Asian Civilizations Museum (Photo: Kenneth Hall)

Tang rulers (618-907 CE) instead promoted the oceanic passageway, as it better suited China's profitable trade in ceramics.

The Changsha bowls are distinctive in their decorations, which anticipated the variety of their Indian Ocean marketplaces. The decorative motifs include Buddhist lotus symbols, as well as makara fish and Chinese calligraphy for Buddhists; geometric decorations and Quranic inscriptions for Islamic markets; and white ceramic ware and green-splashed bowls popular among Persian consumers (Fig. 1). One bowl is inscribed with five loose vertical lines, thought to be symbolic of Allah. There were 763 inkpots (as the Abbasid-era, 750-1258 $\mathrm{CE}$, was notable for handwritten rather than printed texts), 915 spice jars (appropriate for the storage of the valuable Indian Ocean spices, including those of the Indonesia archipelago, that made their way to Middle Eastern marketplaces), and 1,635 ewers (spouted ceramic water vessels appropriate for water pouring) that were also in high demand in contemporary Middle Eastern markets (Hall 2010b).

This and other recent shipwreck recoveries clearly indicate that regional political boundaries during the pre-1500 era were never absolute relative to Indian Ocean sojourning trade, traders, and various 'men of ideas' such as Ibn Battuta [who traveled in Asia from c. 1325-1354] and the Tang and Ming dynasty scribes who recorded and mapped the pre-1500 voyages, as these have been documented and detailed by recent archaeological recoveries from contemporary Southeast Asia port-sites. Collectively these contemporary sources lend credence to notions of variable networked 'borderless' east-west transits in the pre-1500 eastern Indian Ocean, and a sense of an inclusive Indian Ocean passageway that is portrayed in early Chinese maps (Miksic 2013; Wade 2015, 2016). 


\section{Sojourning and Residential Trade Communities in the Pre-l 500 Southeast Asia Region}

Clearly the modern day Southeast Asia region was a major oceanic transit zone and as well a destination on the pre-1500 international East-West 'Maritime Silk Road' connecting the Middle East, South Asia, and China. The Southeast Asia region's prominent maritime activity zones were product sources and marketplaces, as also short-term or longer term residential centers of sojourning traders and Buddhist, Hindu, and Islamic clerics, artisans, and political dignitaries. Until the last decades of the twentieth century Western scholars tended to think of early Indian Ocean trade as based in contained regional political and port spaces adjacent to and distinct from regional upstreams and hinterlands. In contrast, revisionist scholarship has perceived the eastern Indian Ocean maritime regions as open sojourning spaces characterized by fluid borders among a series of networked centers and regions of production, marketing, and port and upstream/hinterland activities characterized by a variety of residential and periodic uses including commodity, human, and knowledge transfers (Calo 2014; Wade 2015; Lammerts, ed. 2014). Current studies that address the inclusive eastern Indian Ocean realm have moved beyond thinking in terms of absolute societal boundaries to better understand the variability of early eastern Indian Ocean networked communities. What is now known as Indonesia, Vietnam, Thailand, and Malaysia, among others, are modern spatially defined regional polities that are legacies of colonial-era boundary divisions that were intended to contain heterogeneous regional populations who had previously had greater opportunity for fluidity (Manguin 2002; Miksic 2013; Whitmore 2017b).

The eastern Indian Ocean region in the pre-1500 age was by nature an area of few impenetrable physical or human boundaries with extensive coastlines and riverine systems that connected upstreams and downstreams to a variety of coastal ports as depicted in early regional chronicles (Hall 2001; Wade 2009, 2013; Gaynor 2013). There was periodic change as one port-of-trade and its upstream was replaced as the 'favored port/coastline' due to variable internal and external circumstances. In this era population clusters were normally separated physically and by self-definition into distinct activity zones, often within a singular or allied network of coastline and river systems as perceived in the representative contemporary Chinese map (Fig. 2). There were rarely contiguous borders as regions were historically under-populated, especially on their peripheries, and political power was marked less by control of geographical space but by the number of residents a ruler could depend upon to remain loyal and who would share their resources for the common good or profit (Aung Thwin 1983; Gommans and Leider 2002). Cultural crossovers were common, and newcomers were welcomed as additional human resources rather than as liabilities (L. Andaya 2008; Lieberman 2010, 2011) (See Map 2). 


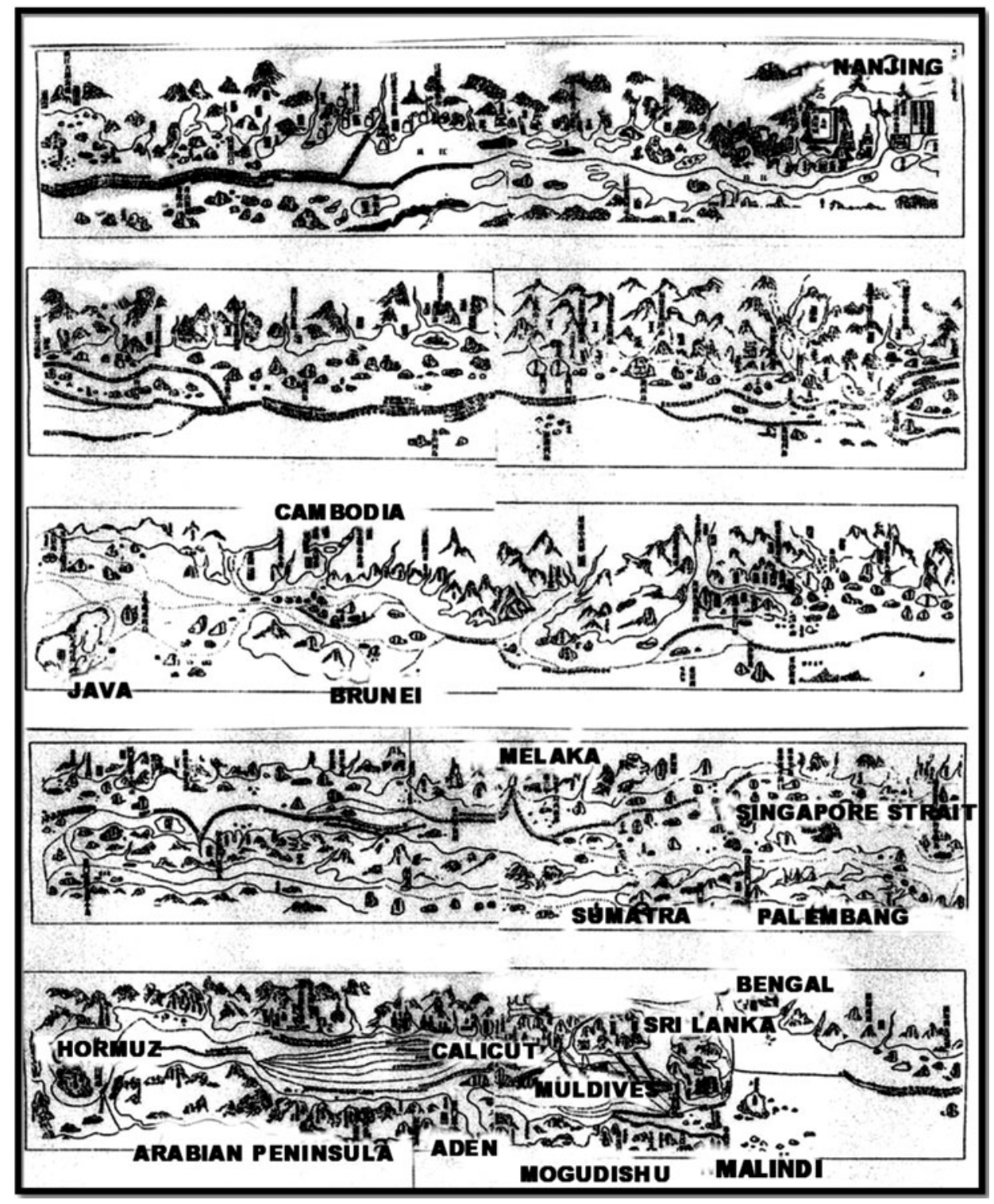

Figure 2. Fifteenth century view of the inclusive Indian Ocean maritime trade route from China to the West in Jia Dan's depiction of Zheng He's early fifteenth century voyages. (Adapted from "A Reconstructed Sea Chart of Zheng He's Maritime Route" in Mao Yuanyi’s 茅元儀 The Treatise of Military Preparation (Wubei zhi 武備志) [c. 1621] (Park 2011))

This fluidity differs from China's history that is concerned with the political consequences of overpopulation, disrespect for traditional societal hierarchy, and the administration of populations who reside within the inclusive boundaries of the chiefly agrarian Chinese state (Chaffee 2006, 2008; Clark 1991, 2015). By necessity a new China dynasty had to reconquer 'rightful' Chinese territory so as to fulfill Confucian expectations of those who claimed and then reestablished 


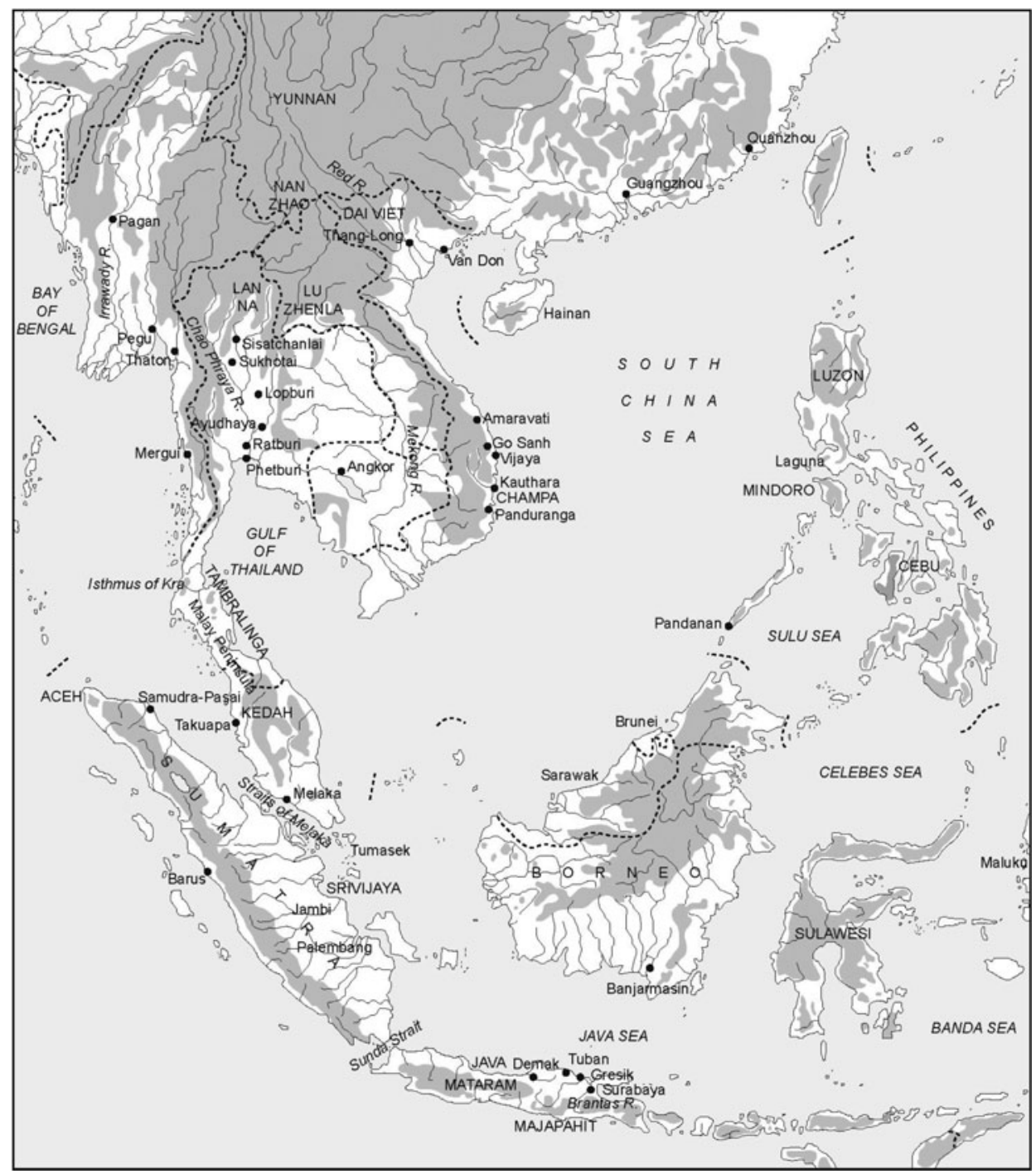

Map 2. Southeast Asia c. 1000-1500

imperial control. In the Chinese aristocracy's mind, maritime activity was peripheral to China's agricultural landed core. By contrast, Southeast Asia's pre-1500 polities were relatively open, people-centered and underpopulated realms in which non-contiguous population clusters had considerable autonomy, including, if they wished, the opportunity to embrace new external commercial, religious, cultural, and political opportunities. The Southeast Asia region's population clusters were more fluid than those of China, as they were open to and embraced the periodic influx of new residents as resources who brought with them their own variety of negotiable cultural practices (Bronson 1992; Miksic 2013).

The following account of a Chinese merchant who traded in south and central Champa (Vietnam) coastline ports during the late twelfth century 
provides a window on the interactions among China-based officials, Southeast Asia port-of-trade rulers, and 'foreign' traders (especially south China diaspora merchants who had resettled in the Southeast Asia region) as it details the multiple networked relationships of a representative Chinese merchant sojourner:

"Wang Yuanmao was a Quanzhou [port-of-trade] man. In his youth he worked as a mere handyman in a [Chan] Buddhist monastery. His masters taught him how to read the books of the southern barbarian lands, with all of which he was able to become closely acquainted; and he accompanied sea-going junks to Champa. The monarch of that country admired his ability to read both barbarian and Chinese books, invited him to become a member of his staff, and gave him one of his daughters in marriage. Wang lingered for ten years before returning (to China), with a bridal trousseau worth a million strings of cash. His lust for gain became fiercer, and he next went trading [in the South China Sea] as the master of a sea-going junk. His wealth became limitless and both Prime Minister Lie Cheng and Vice-Minister Juge Tingrui formed marriage connections with him (through their children). In 1178 he dispatched his borrower [xingqian] Wu Da to act as head merchant [gangshou] on a ship setting out to [the Southern Seas] with a total crew of thirty-eight men under a chief mate. They were away for ten years, returning in the seventh moon of 1188, anchoring south of Luofu Mountain in Huizhou. They had obtained profits of several thousand percent." (Yoshinobu 1970: 192-3)

This Chinese account is consistent with the variety of regional evidence of the Jiaozhi Yang Vietnam coastline maritime network cited above, as this and other Chinese sources allow historians to achieve a better sense of the meaning and significance of the overlapping local and wider political, economic, religious, and societal extended eastern Indian Ocean regional settings. From the late Song dynasty era numbers of Chinese resident in the Southeast Asia region, like Wang Yuanmao, were acculturating into local societies, or negotiating relationships with their neighboring communities as these networked relationships were vital to their personal success. Wang Yuanmao's biography is notable not only for the accounting of his career as a sojourning entrepreneur, but also in its address to his foundational training in a Buddhist monastery that provided the educational and religious base for his subsequent successful commercial career. This accounting is consistent with new studies of Indian Ocean maritime diaspora communities that commonly find similar cross-references to a merchant sojourner's religious identity, indicating that religious affiliations were meaningful among Indian Ocean maritime diaspora communities (Clark 1991; Mair and Kelley 2015). In several cases south China linked diaspora were noted to be variable patrons of Islam, while others subsidized shrines dedicated to the local divinity of their home port-of-trade, and those like Wang Yuanmao sustained 
temples in their residential ports and networked upstreams that were institutionally linked to south China Mahayana Chan/Zen Buddhist 'mother' temples. This key ingredient of variable cultural affiliation among Chinese sojourning diaspora is overlooked in exclusively economic and political focused studies, as these ignore the vital role that Chinese maritime diaspora assumed in the creation of the new 'borderless' culturally networked communities in the regions to China's south, as shared cultural/religious exchanges with local populations were foundational to collective Chinese and local ethnicity economic and political opportunities (Clark 2011; Gunn 2011; Whitmore 2017b).

These new cultural options set in motion wider regional change, less due to replication of China and more to a 'localization' in which the resident community made modifications of their cultural practices as appropriate to indigenous needs and opportunities. Such Southeast Asia localizations commonly reinforced new highland-lowland and upstream-downstream networking potentials as these were characteristics of then stabile Southeast Asian societies (L. Andaya 2008; Gaynor 2013). Adaptive cultural networking most often resulted from Southeast Asia's prominent intermediary position in the oceanic trade routes, as these ongoing contacts provided the double potential for cultural interactions between locals and the variety of international sojourners, and access to the assorted foreign goods, services, and ideas they provided (Hall 2013). There were alternative opportunities for overland communication, as for example the longstanding networking and transit of populations and commodities across the south China borderlands into what is today Myanmar, Thailand, Cambodia, and Vietnam that included the exchanges of horses, elephants, cowrie shells, silver bullion and coinage, and Buddhist theology and other knowledge exchanges (Heng 2006; Yang 2004, 2011; Sen 2014).

Marginalization of Southeast Asia's multi-dimensional engagements in the eastern Indian Ocean region is in part the product of a view initially argued and then retracted by the Southeast Asia historian O. W. Wolters in the late 1960s (Wolters 1967, 1970, 1982), that the entry and residency of foreign merchants in the early Southeast Asian region was cyclical and tied to the opening and closing of China's ports, or responded to unstable political and societal factors on the western and eastern ends of the international maritime route (Wolters 1979; Abu-Lughod 1989; Gunder Frank 1998). Such a view assumed that the maritime route depended on the marketplaces at the route's ends in China, South Asia, and the Middle East, as these primary civilizations offered sufficient commercial potential and cultural opportunities to encourage trade in their networked secondary societies. In the reverse, if the primary marketplaces in the Middle East, South Asia, or China closed or were not accessible due to some local crisis, then international traders had less incentive to make the maritime passage, or alternatively settle in Southeast Asia's prosperous port regions. Regions that lay between China and South Asia suffered through periodic commercial downfalls accordingly, and resulting economic recessions 
initiated the fall of existing regional polities that overly depended on trade-engendered revenues. Sequentially new or recovering Middle East, South Asia, or China-based polities offered stable markets for the renewal and expansion of assorted Eastern Indian Ocean exchanges.

One objection to this overview of the prevailing patterns of exchange as endproducts of China or India-linked engagements in the Southeast Asia regions is that it reinforces an emphasis on the external as the motor for change in the Southeast Asia region, and fails to recognize localizations in the development of marketplaces and civilizations within the region that lay not at the ends and middle of the route but along the route's entirety, and local capacity to become culturally creative as well as major consumers of the variety of Indian Ocean products on their own. One may alternatively argue, as for example in the cases of the Bay of Bengal, South China Sea, Java Sea, and linked eastern Indonesian archipelago regional networks connected to the major east-west maritime route, that once set in motion the various Southeast Asia centers of trade and their adjacent civilizations became so trade-centered that they could sustain an international route even without the participation of major consumer markets on their eastern or western oceanic ends (Ptak 1992, 1993, 1998a, 1998b; Subrahmanyam 1999; Wisseman Christie 1999; Kulke 1999).

Scholars have assumed that merchants flocked to the Indian Ocean route in good times, because a market upswing increased their likelihood of profit (Abu Lughod 1989). That is, traders would risk the uncertain voyages because they seemed assured of a significant material return for their initiatives and efforts. However, there was equal possibility that traders' willingness to venture overseas was induced by a depressed market or unstable circumstances in their homeland, and that their entrepreneurial initiatives were the consequence of the practical necessity of seeking a living elsewhere. Southeast Asia's developing civilizations and their marketplaces certainly offered an attractive alternative (Hall 2001; Wheeler 2011). Even the old view that there was a vital dependency on the ebb and flow in the volume of trade at China's and Middle East ports that resulted from dynastic transitions and changing government attitudes toward trade and traders has been challenged. Historians who specialize in China’s history now question whether there were really significant periodic declines in China's trade volume, and assert that actual practice was quite different from the rhetoric in the official state documents (Kayoko, Shiro, and Reid 2013).

The increasing presence of foreign merchants and others in Southeast Asia, while in part the consequence of an expansive international marketplace, must also be considered as potentially resulting from economic or political failures in their homelands. For example, in the era of the Mongol conquests numerous regional populations responded by moving to more secure settings. Thus, numerous professionals from the Persian realms of modern-day Iran took residency in South Asia and the regions beyond during the thirteenth century, as Persia-based merchants had relocated or converted to Islam when the Persian Empire fell to 
Muslim armies in the seventh century (Sims-Williams 1994; Sen 2003). Similarly, following the collapse of the Gupta realm in north India during the late sixth century, and again after the surrender of northern India to Muslim warriors in the eleventh century, numerous Hindu and Buddhist clerics found alternative employment in the service of south India's kings and in Southeast Asia's courts (Lieberman 2003, 2011; Asher and Talbot 2006). Clerical 'knowledge agents' of Islam in Southeast Asia included Java's mystically/spiritually endowed wali sanga [saints] and increasing numbers of sojourners with Middle Eastern roots who sought alternative residencies coincidental to the 1258 fall of the Abbasid dynasty in the Middle East and periodic insecurities during the era of the Delhi Sultanate in twelfth through sixteenth century northern India (Lambourn 2008; Wade 2010).

Migrations of Chinese merchants into Southeast Asia were initially encouraged by Chinese officials in the Song era to secure more product volume from the regions to the south for domestic consumption as well as to enhance the China state's tax revenues, as the Song relaxed their previous travel restrictions on the Chinese merchant community. When the existing overseas-based traders network was not supplying sufficient commodity volume at the Chinese ports, China's port agents modified prior restrictions in dispatching Chinese merchant diaspora as a means to acquire additional tariff revenues, and to supply the Chinese aristocracy with the foreign commodities that were necessary in their ritual performances and conspicuous public displays (Shiro 1998; Sen 2003; Shiro and Takashi 2013; Chin 2013). Equally, sojourning was a means by which southern Chinese sought income that could sustain themselves and their families in desperate times whether economically, politically, or culturally challenging, as migration to the South was a logical and viable option (Chang 1991). Thus the greatest eras of Chinese migration into Southeast Asia and the establishment of Chinese diaspora communities in regional downstreams corresponded to the bad times and public disorders associated with declining or failed dynasties, as for example the fall of the Song (1279) and the rise of the Yuan (1271), or the fall of the Yuan and the rise of the Ming (1368) (Clark 1991; Ptak 1998a; Sen 2003; So 1998, 2000; Whitmore 2014).

Southeast Asia's acceptance as a strategic international trade intermediary as also a product source implies the periodic residence of traders and seagoing groups, who had to make stopovers waiting for a shift in the wind patterns that would allow them to return to their home ports. By at least the eleventh century sailors and traders rarely made the entire East-West passage, but only specialized in one portion of the route, and transferred their goods to and interacted with merchants and sojourners from other sectors of the passageway at a Southeast Asia regional port-polity. Southeast Asia's regional port-polity populations were thus in a constant state of flux, based on the wind patterns favorable to oceanic transit as well as the local market's potential as a source of international goods and/or local products. 
One temporary resident population might replace another when ships arrived from an adjacent segment of the international passage (for example, from the South Asia coastline to Southeast Asia ports or from China to Southeast Asia ports) after the transitory residents embarked with the prior season's monsoon winds. Thus, historians have been reluctant to identify early Southeast Asian portpolities as legitimate cities, on the grounds that they might only have a large seasonally resident population dictated by monsoon wind patterns, but were the continuous homes of only a small number of year-round occupants (Wheatley 1983; Wisseman-Christie 1992; Heng 2009; Miksic 2013). And even these 'permanent' residents might make frequent passages between their port-polity downstream and its domestic upstream and linked coastal hinterlands. There sojourners who were wholesalers or petty traders exchanged their homeport's products for domestic commodities and manufactures in well-developed and hierarchical indigenous marketing systems (Bronson 1992; Wisseman Christie 1999; Hall 2013).

As noted, the Southeast Asia region was widely regarded as an important commercial exchange nexus for commodities from China and the West, as well as its own spices, exotic jungle products (e.g., rhinoceros horn - a desired aphrodisiac, sandalwood, and tropical birds), and metals (variously tin, silver, and gold). However, to focus exclusively on the international trade ignores the developing hinterland market networks that supplied these products to the ports, as well as the indigenous demand for imported commodities - notably iron (as segments of the Southeast Asia region had an inadequate iron supply), and textiles (especially Indian cottons produced in the Gujarat region of upper west coast India and in the multiple weaving centers of India's east coast). Ceramics, and, in the time of the early Islamic conversions, tombstones were imported from Gujarat and south China (Lambourn 2003, 2008; Hall 2012). The Southeast Asia marketplace was important enough that Indian textiles were manufactured to Southeast Asia-resident specifications, as for example the long pieces of ritual cloth that Gujarat weavers produced to the specifications (size and design) of the Toraja society of the eastern Indonesian archipelago (Wisseman Christie 1993; Hall 1996; Barnes and Kahlenberg 2010). Java’s marketplace was sustained by a realm-wide monetary system based in the use of Chinese coinage that was in place by the thirteenth century, and consequently commodity value was most often determined in monetary terms rather than in reference to bulk. (Aelst 1995; Wisseman Christie 1996; Hall 2010).

\section{Trade and Traders in the Early Eastern Indian Ocean Maritime Region}

What, then, were the characteristics of the trade and traders who participated in the Southeast Asian portion of the early international maritime route? Because of their varying transitory regional stopovers the maritime traders may be thought of 
as members of fluid communities in motion, who individually or collectively reconceptualize themselves relative to what and who they represented in everchanging circumstances. Those who became local residents, if only for a short time, had to make the best of the circumstances in a setting in which there was an ongoing process of creativity and negotiation of identity (Ellen 2003; Hall 2011, 2013).

Membership in Southeast Asia's coastal communities was open to those who would risk the voyages and hardships of living in a foreign environment with limited cultural amenities. International seafarers had to accept their place in or among communities that consisted of their fellow transients and resident commercial specialists, or combinations of commercial specialists and other local residents. Community membership could be assigned by the itinerant merchants themselves, resident merchants, indigenous elite, or by mixtures thereof. Membership could be determined by internal or external factors, or both (Manguin 1993, 2002; Heng 2008).

One can speak of multiple "fields of representation" associated with merchant communities, wherein early Southeast Asian merchants moved through cores and zones from which they derived their identities (Hall 2013: 222-231). In the early Southeast Asian epigraphic sources merchants were not usually identified by their specific port of origin as is more typical of the post- 1500 chronicle literature, but by their association with a regional core. A core might be the principle source of a major commodity, for example an entrepôt or region where certain products were available: tea (China), frankincense (Srivijaya), camphor (Barus), cloth (Kelinga), pepper (Samudra-Pasai, Banjarmasin), and spices (Java) imparted an associated identity. However, the Kelinga, Cham, and Khmer categorical generalizations in Java inscriptions and regional chronicle texts also imply an associated ethnicity. Chinese dynastic records provide recognition of the different ethnicities who were members of tribute delegations that arrived at the Chinese court. Among the most prominently mentioned were the intermediary Keling Muslim merchants based in southeast India who were also linked to Middle East ports-of-trade (Sen 2003; Heng 2009; Miksic 2013). Zonal identification derived from a merchant's travels within a specific sector of the trade route that were in part dictated by the seasonal monsoon winds, for example the Bay of Bengal, South China Sea, and Java Sea networks (Ptak 1992, 1998; Frasch 1998; Subrahmanyan 1999; Hall 2011). Merchants acquired local products within these networks that they would take elsewhere; in exchange they left their own trade commodities (e.g., textiles, ceramics, and/or spices) that were adopted and adapted into local communities, as potentially the merchants were themselves (Heng 2006). A surviving fourteenth century Sumatra upstream Malay language legal text includes references to imported spices and other commodities that derived from local networking with downstream traders, as these international items had recorded value in the itemized Sumatra upstream code that favored commodity rather than monetary exchange (Miksic 2009; Kozok, 


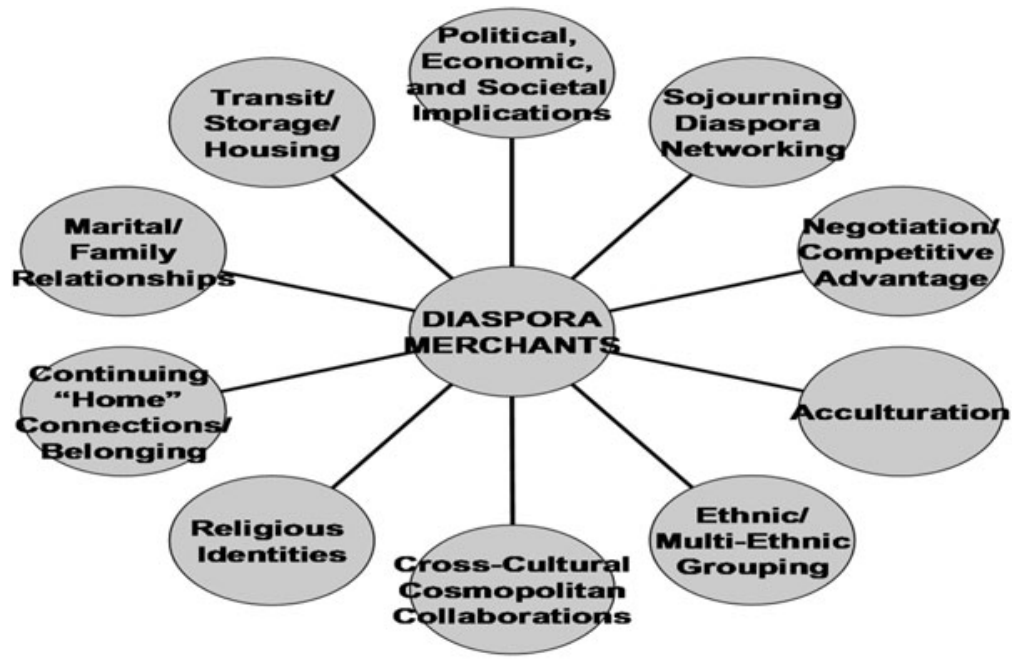

Figure 3. Networked Indian Ocean maritime diaspora linkages. (Kenneth Hall)

et al. 2015). According to the Chinese dynastic records, Southeast Asia-based merchants traded as the representative agents of specific ports and served as members of these ports' trade and tributary delegations, and therein the Chinese records ascribed their community membership. For example, Muslim traders, who may or may not have had a Middle East origin, were regularly accounted as participants in the Southeast Asia tributary missions to the Chinese court from the eleventh century (Sen 2003; Heng 2008). The frequent presence of Muslim traders among the embassy delegations was noteworthy enough to have warranted distinctive Chinese recognition, with the implication that these diaspora in some way assured the quality of trade and the types and value of goods an alien port provided to China's marketplace (Wade 2013; Sen 2014) (see Fig. 3).

Diaspora traders could become locally prominent. The earliest Southeast Asia example is a seventh century southern Vietnam inscription that records the Kaundinya myth commonly shared among early mainland Southeast Asian societies, wherein a South Asian sojourner married a local princess and therein initiated local kingship (Vickery 2003). Among later examples is the legend of the early sixteenth century northeast coast Java Demak ruler who, after making strategic stops in major networked ports-of-trade on the Sumatra and Java coastlines ultimately married an east Java Majapahit court princess, thus symbolizing his prominent northwest Java port's legitimacy as the heir to the previously dominant upstream-based court (Hall 2014a). There is also the Thai record of a member of a Chinese merchant diaspora household who eventually became the ruler of the regionally powerful Ayutthaya realm. According to the Thai chronicles:

"The [previous] king passed away and no member of the royal family could be found to succeed him. So all the people praised Prince U Thong, who was the son of the leader of the Chinese merchant 
community [who was well-connected to two powerful Thai clan networks in the upstream Suphanburi and Lopburi regions], to be anointed as king to govern the kingdom [in due course he strategically resettled his upstream and downstream supporters in and around his new intermediate downstream Ayutthaya capital city in 1351]" (Gilman d' Arcy Paul 1967: 37).

Port-polity authorities were expected to protect all involved in exchanges from undo exploitation, to insure that trade was transacted according to a commonly established and accepted standard of conduct and even a common code of law, as demonstrated in the fourteenth century compilation of the Melaka Maritime Laws (Winstedt and Jong 1956). Melaka's rulers reasoned that local prosperity was due to retention of locally based and seasonal sojourning diaspora traders, and thus sponsored a legal declaration favorable to Melaka's multi-ethnic marketplace participants. By doing so, Melaka's monarchs allowed its multi-ethnic trade community some latitude rather than severely restricting their variety of activities, but regularly confined them to their port residency or anchorage, thereby limiting their access to regional upstreams (Heng 2009; Miksic 2013).

There were 'circles of rivalry' in the eastern Indian Ocean trade network: between merchants and locals and among the sojourners themselves. Rulers and other locally powerful persons - landholding elders, empowering priests, or governmental elites - frequently viewed the actions of 'outsider' merchants as threats to their reciprocity-based local networks (Hall 2010). This is demonstrated in the restrictions placed on merchants and other local and foreign professionals by early Java monarchs, who limited the number of merchant/ professionals who were allowed to become local residents (Wisseman Christie 1998). Contemporary Cham inscriptions recovered from the Vietnam coastline report the purposeful isolation of sojourning traders in coastal enclaves on the society's periphery (Hall 2011; Whitmore 2017a, 2017b). But merchants and other foreigners were regularly recruited into the regional political systems due to their status as 'outsider' non-integrated members of local society, frequently as a monarch's tax collectors (Hall 2013).

Competition among the merchant communities themselves is demonstrated in the recurrent references to the raiding of rival ports-of-trade, as for example early southeast Sumatra-based Srivijaya's aggression against contending north Java and Melaka Straits regional ports and subsequent south Indian Chola maritime raids on Srivijaya's ports in 1025. The Chola maritime raids against Srivijaya's networked ports are reported in Chola inscriptions as well as in Chinese dynastic records, as are contemporary Chola maritime aggressions against regional Bay of Bengal ports-of-trade. These were likely related to contemporary Chola interests in having some degree of profitable return from the Bay of Bengal, Straits of Melaka, and South China Sea trade route in support of south Indiabased merchants. That a Chola-sponsored Hindu temple at Quanzhou modeled on the Meenakshi temple at Madurai was said to have been financed 
by Chola rulers in partnership with full- or part-time resident south India diaspora merchants points to these kinds of long-distance relationships (Guy 2001; Kulke, Kesavapany, and Sukhuja, eds. 2009; Hall 2014b).

Thai and Java-based raiders were common in the Straits of Melaka region in the fourteenth century; similarly Cham courts had an interest in southern Vietnam staged raids against their western Khmer and northern Vietnamese neighbors in the eleventh through fifteenth centuries (Heng 2009; Miksic 2013; Whitmore 2017a, 2017b). Pre-1500 Straits of Melaka chronicle literature, including the Hikayat Raja-Raja Pasai of the fourteenth-fifteenth century northeast Sumatra port-polity, record periodic raiding against ports-of-trade on the Sumatra and Straits of Melaka coastline (Hall 2017). These raids have too frequently been characterized as political competition, attempts to acquire dependent labor, or to acquire plunder. In an alternative view, regional political ambitions were increasingly related to a court's commitment to support and consolidate a regional trading network rather than periodically pillaging its competitors (Hall 2011). For example, the northeast Sumatra Samudra-Pasai port was initially known as a pepper marketplace, but eventually consolidated its control of northwest Sumatra Barus' camphor and benzoin. Prior to Melaka's rise to prominence it was the Straits premier marketplace with regular access to eastern Indonesian archipelago nutmeg, cloves, mace, and other spices (Hall 2001; Miksic 2013).

Raids on a competing port or region did secure valuable plunder and manpower, but also desecrated one's rival(s), and in various ways discouraged competitive trade at a rival's port(s) or superseded their competition in the regional and international trade network (Manguin 2002; Reid 2000). The following graphic (Fig. 4) depicts the complexity and multiple transactions centered in the c. 1200-1500 northeast Sumatra Samudra-Pasai port-polity as detailed in its contemporary court-chronicle and confirmed in the accounts of visiting sojourners, among these Ibn Battuta in 1346 (Gibb 1957; Hall 2001, 2017),

These maritime competitions included merchant communities and/or drew upon their resources, minimally as the source of ships and provisions, as well as seafaring warriors. In an early Srivijaya inscription a ship-owner was the acknowledged source of vessels for the Srivijaya monarch's expeditions against his rivals (Manguin 2016). Fifteenth century Java port-polities were planning a raid on Melaka even before Portuguese conquest in 1511, and a regional alliance subsequently attacked Portuguese Melaka in an attempt to displace Portuguese control of the strategic port, intending to divert its monopolistic trade to other regional port-polities (Manguin 1991). With the fall of Melaka in 1511, numbers of maritime diaspora relocated to Demak on Java's northeast coast, Banjarmasin in southeast Borneo, Aceh in north Sumatra, and Thai Ayutthaya to the north (Hall 2014a).

It is unrealistic and improbable to assume that there was a generalized brotherhood among the merchants, although merchants periodically shared a common place of residence, and also religion. One needs to be careful not to envision 


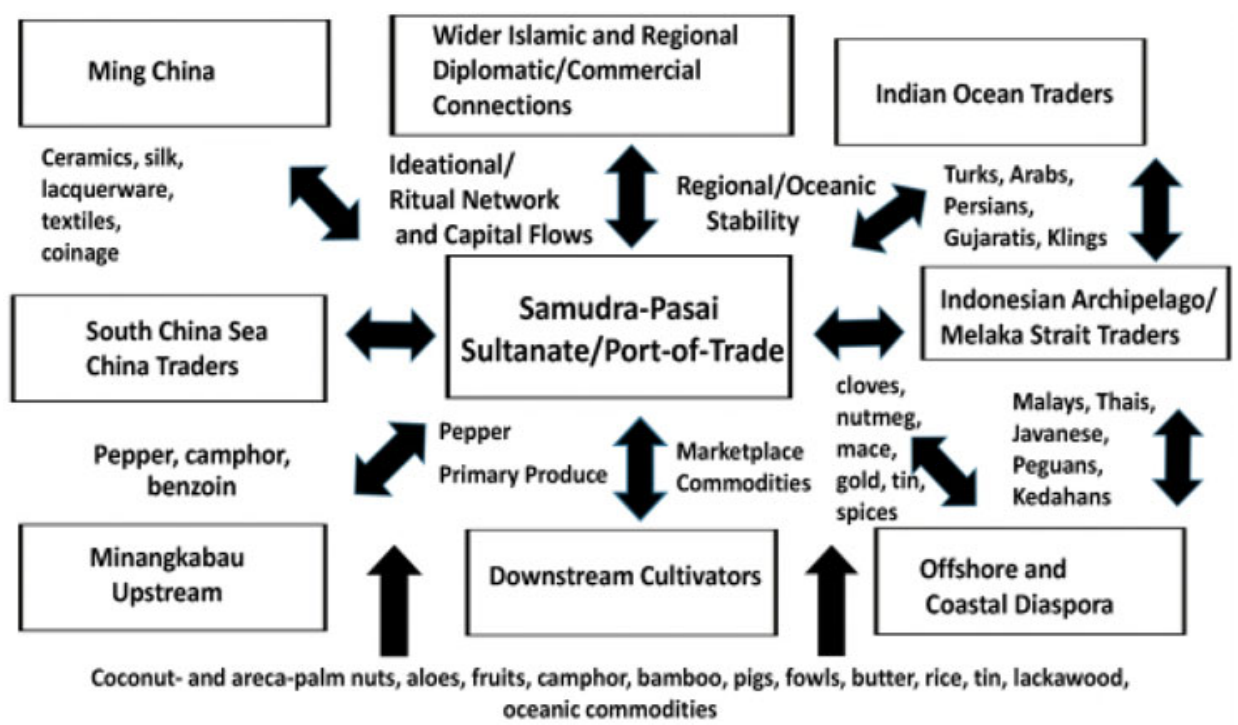

Figure 4. Networking and commodity flows of the c. 1200-1500 Samudra-Pasai portpolity as identified in the Hikayat Raja-Raja Pasai. (Kenneth Hall)

clear-cut dichotomies at work when discussing these early merchant communities, as for example the still too frequent mistaken generalization that all Muslim traders were Middle East-based 'Arabs' (Ray 1994; Sen 2003), as similarly that all Chinese and South Asians were inclusively 'Chinese' and 'Indians' (Chang 1991; Ptak 1998; Salmon 2002). Another notable misrepresentation is the bipolar distinction between sedentary merchants (i.e., those assumed to be residential) and others who were locally mobile (i.e., transient). Clearly, due to the seasonal shifting winds of the monsoons, Indian Ocean sojourning merchants were sometimes primarily mobile and othertimes sedentary. However often those from a maritime diaspora who were based in a specific port and did not make the seasonal oceanic voyages were also locally mobile, as for example when they traveled inland/upstream to market or to gather products, or as they regularly took short trips to a series of networked regional ports-of-trade (Kathirithamby-Wells and Villiers 1990; Gaynor 2013). Maps of fifteenth century Melaka demonstrate clustered residencies of Chinese, South Asian, Middle Eastern, and other maritime diaspora, as this was similarly the pattern in other prominent fifteenth century Southeast Asia ports (Map 3).

In maritime Southeast Asia there has always been an itinerant community of upstream and downstream and coastal-networking seafarers who, based out of a home port, acted as the vital intermediaries between major ports-of-trade and communities in the adjacent river mouths and their upstreams. Downstream based vessels of assorted sizes gathered and relocated products, as the residents of a port-of-trade network in a variety of ways acted as intermediaries in both the international and indigenous marketplaces (Tan 2012). Where do these 


\section{MELAKA URBAN CORE C. 1500}

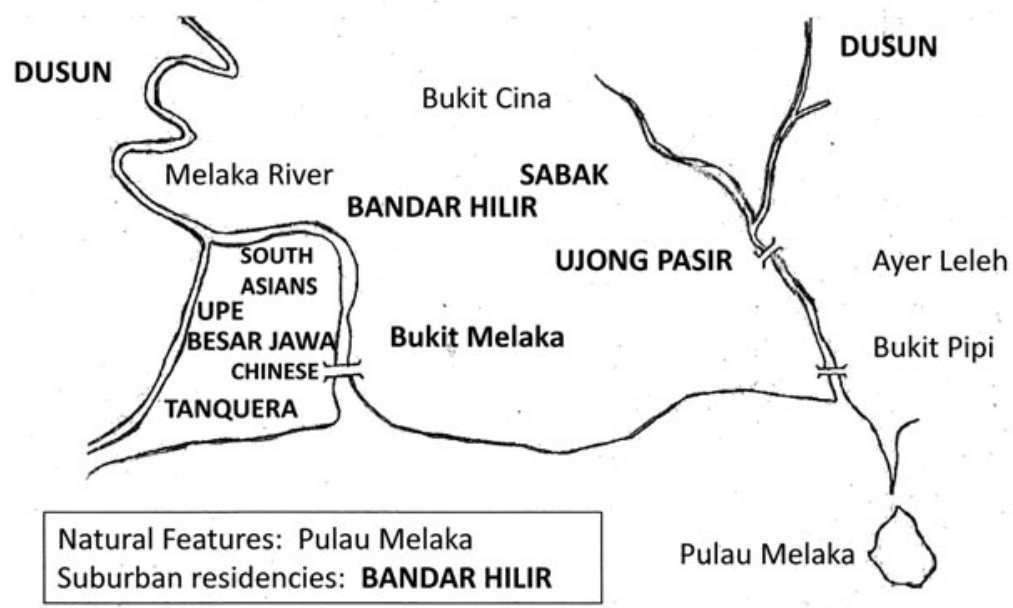

Map 3: The Melaka urban core 'Activity Zone’ c. 1500. (Kenneth Hall)

intermediary sojourners fit in the overall configuration of early Southeast Asian trade communities, and what was the nature of and the consequence of these merchants' local networking relative to international trade and traders? Recent studies of the Bugis and other sojourning maritime community networks within Southeast Asia's eastern archipelago provide clues, and even conclude that post-1500 eastern archipelago itinerant communities became the basis of their own networked 'cultural state' (L. Andaya 1993; Ellen 2003; Gaynor 2016).

In addressing the character of the port communities populated by a mix of international sojourners, who were forced to lay over until the next monsoon season as these contrasted to 'continuous' residents, we know that itinerant Chinese merchant diaspora frequently married and had a network of wives and families resident among the ports in which they did business, as in the previously cited example. Wives and families looked after their extended family's interests when Chinese merchant sojourners traveled to other ports (Chang 1991; Manguin 1991; Reid 1996). That non-Chinese merchants were also likely to intermarry and establish some form of continuing community membership is demonstrated in the contemporary records of the sojourning Hadrami and 'Persian' merchant communities (Ho 2006). Hadrami merchants were resident in most of the major ports-of-trade between Yemen and Melaka by 1500 , where their local presence was balanced by their responsibilities and continued interactions with their international network in which ports on the Gujarat and the Malabar coastline on India's west coast assumed particular importance. Socalled 'Persian' merchants who were based in Masulipatnam and other upper Bay of Bengal regional ports by the fifteenth century also had ongoing connections to the Iranian region. This 'Persian' merchant community dates to the earliest centuries of the first millennium, when Chinese diplomats who traveled 
between China and India repeatedly referenced resident and itinerant Sogdian merchants then active in Southeast Asia's ports-of-trade (Subrahmanyam 1999; Sen 2003). Networking from a common point of origin was also characteristic of other merchant diaspora, as the Cairo Geniza records document Egyptian Fustat-connected Indian Ocean Jewish merchants from the eleventh century (Gil 2003), as was also the case among the Tamil Hindu and Muslim (e.g., Keling) merchant communities discussed above, whose inscriptions and fifteenth century Sejarah Melayu court chronicle records reflect their continuing networked loyalty to their south Indian homeland, as was also acknowledged in contemporary Chinese and Southeast Asian documentation (Hall 2010).

Some historians have argued that Southeast Asia's Islamic conversions were not primarily spiritually motivated but trade-related, to induce specific foreign traders to do business in new Islamic ports with resulting increases in local revenue collections by regional monarchs who were co-religionists (Hall 2001, 2014a). While at this distance in time it is impossible to know why widespread Islamic conversion took place, and there is no reason to doubt the general sincerity of those who did so, there were certainly positive implications consequent to conversion in the reality of economic benefits that derived from the conversions of local rulers and traders. In this view Southeast Asia rulers sought to attract Muslim traders, who were by the thirteenth century preeminent on the international route between the Middle East and China, and induced these seafarers to make their monsoon layovers in Muslim ports rather than others. Local conversions implied a favorable religious environment and the assurance of the local acceptance of the Islamic moral code, at least as this applied to commercial if not personal transactions.

Notably, coastal port-polity elites were among the first converts to Islam, and only later did their adjacent upstream hinterland populations join them. The hinterland populations seemingly had little initial incentive to accept Islam, since their community membership was already satisfied by traditional non-Islamic standards of interaction. Eventually upstream conversions to Islam took place through the agency of downstream rulers, who encouraged local acceptance of Islam as a means to legitimize their own local authority, and also to increase the flow of hinterland produce to downstream ports (Hall 2016). Thus, this local patronage of Islamic merchants and local conversions to Islam may have initially been only token gestures meant to derive economic benefits; the conversion equally could draw on Islam's political potential to link diverse upstream and downstream population clusters into a common cultural community, or in a more positive light, conversion resulted in a political elite's genuine spiritual commitment that could sustain more practical and mundane societal goals (Hall 2001; Wade 2010).

Generally historians have been reluctant to see merchant sojourners as sources of cultural transmission, instead crediting priests, monks, and scholar 'knowledge practioners' who took passage alongside them (Morillo 2011). 


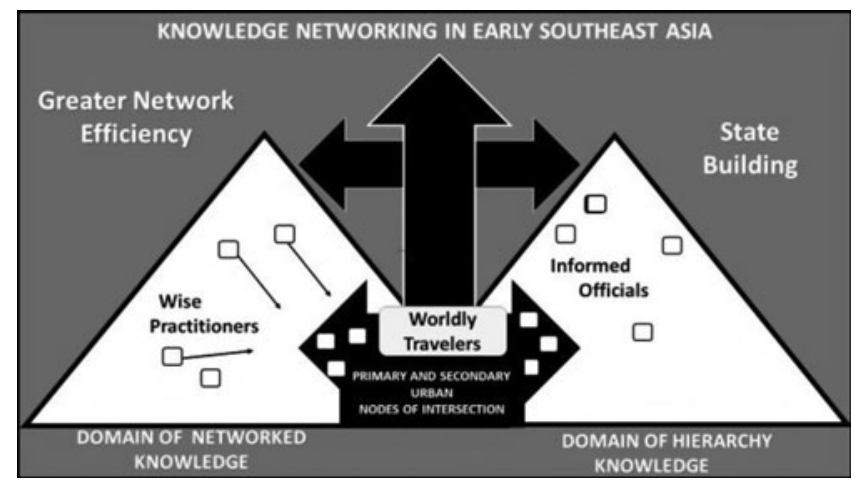

Figure 5. Knowledge networking in pre-1500 Southeast Asia. (Kenneth Hall)

Merchant groups who associated with and patronized the Muslim, Buddhist, Indic, and Chinese cultural realms had connections that undoubtedly offered them opportunities for cultural brokering. Merchant and sailor 'worldly travelers' were not devoid of culture as their worldly travels made them culturally sensitive to the issues of inclusion rather than exclusion. Diaspora populations financed temples, retreats, and mosques to facilitate, promote, and substantiate their role as members in a ritual community - with focus on their pursuit of societal well-being as rightful and contributing members of a society rather than being obsessed with achieving their personal gain at the expense of others (Kulke 1993; Lambourn 2011). It was important that c. 1400 merchants focused on Indic, Muslim, or Chinese contributions to world order as the source of their own legitimacy and a sense of place, to neutralize local characterizations as 'outsiders' that were not complementary, and to mobilize against likely and personal threats to their well-being (Hall 2011; Morillo 2011; Lambourn 2011; Whitmore 2011). The potentials of international knowledge transfers are depicted in the graphic above (Fig. 5).

\section{Contested Agencies in the Fifteenth Century Straits of Melaka Region}

Based on the cited Southeast Asia evidence, revisionists assert that from the late thirteenth through early fifteenth century (in the eras of late Yuan and early Ming sovereignty) enhanced Chinese diplomatic agencies in the Southeast Asia region were less about confirming Chinese regional sovereignty over the maritime passageway, and more about soliciting tributary trade that would supply China's marketplace demand for Indian Ocean products, and therein increase the volume of taxable international trade taking place in China's ports. Thus, Yuan and Ming court regional outreach initiatives were less reactive to a generalized decline of China's maritime trade, or due to China's expansionist dynastic ambitions, but 
resulted from dynastic concern that China was being relegated to the periphery of the Indian Ocean maritime world. Therein Yuan and early Ming monarchs supported diplomatic attempts to recover some of the lost trade volume that was going to China's Indian Ocean market competition. Before the Ming restricted exports, most notably Chinese ceramics from the 1430s until roughly 1570, during what historians have called the 'Ming gap', China's agents promoted exports (especially ceramics) and welcomed reciprocal foreign trade and embassy delegations, to not only guarantee China's access to the best international products (e.g., spices, regional specialties, and a variety of forest products), but secondarily to reassert China's political interests in the Indian Ocean region, most notably in maintaining the fluidity of the East-West maritime passageway (Brown 2008; Laichen 2013).

In the fifteenth century Melaka rose and provided a singular prominent intermediary marketplace at the intersection of the Bay of Bengal, South China Sea, and Java Sea regional networks. Ming rulers supported the founding of Melaka, and the voyages of the Ming eunuch Admiral Zheng He reflect their attempt to assert and revitalize the Tang-era China-centered tributary trade system (Chang 1991; Wade 2005). However, Ming initiatives ultimately failed, not just because of debate within China itself relative to the appropriateness of China's external initiatives (Wade 2015), but because the old tributary system was no longer valid. Despite what many historians have proposed, China could no longer 'rule the seas', even though they still could send out fleets that included one thousand ton junks. Revisionist historians now depict Ming maritime ventures as attempts to reassert an idealized dynastic past in much the same way that previous Chinese dynasties had repeatedly tried to conquer what they assumed to be the 'natural' regions of Chinese authority, as notably reflected in the repeated and failed attempts of new Chinese dynasties to reassert China's 'rightful' authority over Vietnam from the eleventh century on (Whitmore 1996; Cooke, Tana, and Anderson 2013). Instead, Melaka's rise to prominence by the fifteenth century depended on the complexity of the multicentered trade in the Indian Ocean, and the practicality of establishing a single Southeast Asia clearinghouse for East-West Indian Ocean trade in partnership with China in that era. In essence, it was appropriate that this central entrepôt was in Southeast Asia, because Southeast Asia was geographically the pivotal marketing center of Indian Ocean trade and the strategic source of the most in demand Indian Ocean commodities, notably textiles, ceramics, spices, and metals.

While the remaining records tell us little about the men who traded from fifteenth century Melaka, we know a good deal about its leaders. From the beginning they took great care to make their new port attractive to international traders. As among its predecessors, Melaka's residency patterns ebbed and flowed with the monsoons. Traders and other groups maintained permanent warehouse and residency compounds, the forerunners to the European 
'factories' that were later established at strategic Indian Ocean ports. However, except for a few year-round representatives of the major trading communities, Melaka's population in these compounds was seasonal. A special governing body and judicial system gave visiting merchants and their goods protection while in the port. The main court officials, the Bendahara [prime minister], Laksamana [admiral of the monarch's fleet], Syahbandar [harbor master], and Temenggung [minister of justice, defense, and palace affairs] all facilitated trade in various ways. Melaka's port regulations aided the local exchange of goods so merchants did not find themselves overly burdened. This way they did not stay so long in port that they lost a favorable monsoon wind for their return voyage. There were also regular standardized customs duties as well as fixed weights and measures and units of coinage that helped support marketplace exchanges and generalized stability (Thomaz 1993; Kozok 2015).

Melaka's Malay nobles did not take part in the affairs of the marketplace. They delegated this to the merchants themselves, but they did command the fleet of ships that policed the Straits to keep it free from piracy. In addition, vessels powered by oar rather than sail also patrolled the Straits, so that they could tow becalmed ships into port. Melaka's success enticed regional chiefs, who entered the traditional Straits' alliance networking among rulers and ruled (Milner 1982). Under this agreement, the Melaka monarch made periodic redistributions of wealth to those who remained subordinate to his port-polity, and omitted those who conducted acts of piracy or allied with Melaka's competitors.

The initiatives of Melaka's early rulers laid the foundation for Melaka's international prominence. Heavy naval traffic came via the monsoons from both western and eastern Asia. India-based ships arrived regularly from India's southern coastline, Sri Lanka, and the wider Bay of Bengal coastline. Marketplace commodities included luxury items from the Middle East, such as rosewater, incense, opium, and carpets, as well as seeds and grains, but the bulk of the fifteenth century cargoes from the west were made up of cotton cloth from the Gujarat and Coromandel coasts (Hall 2012). Vessels from Bengal brought foodstuffs, rice, cane sugar, dried and salted meat and fish, preserved vegetables and candied fruits, as well as local white cloth fabrics that could be locally decorated. Malabar merchants from India's southwest coast brought pepper and Middle Eastern goods. The Bago (Pegu) polity in lower Myanmar (Burma) also supplied foodstuffs, rice and sugar, and ships. In return, spices, gold, camphor, tin, sandalwood, alum, and pearls were sent from Melaka, as well as re-exports from China that included porcelain, musk, silk, quicksilver, copper, and vermillion. Malabar and Sumatran pepper was carried to the Bengal coastline for regional distribution, as opium from Middle East was also a Bengal re-export (Meilink-Roelofsz 1955; Wake 1967; Miksic 2013).

Though China may have discouraged official tributary trade with the South after the 1430s, there was still an ample, unofficial and privately financed trade conducted by junks sailing from south China ports and intermediary ports on 
the south and central Vietnam coastline (Wade and Laichen 2010; Whitmore 2017b). Prominent commodities included large quantities of raw and woven silks, damask, satin and brocade, porcelain and pottery, musk, camphor, and pearls, copper, iron, and copper and iron utensils, as well as the less valuable alum, saltpeter, and sulfur that were necessities for early regional gunpowder warfare. Regular shipping transfers also came from Thai Ayutthaya, Vietnam, Java, Borneo, and the Philippines, which contributed foodstuffs, jungle goods, ceramics, and a variety of other trade items (Laichen 2003, 2006, 2011, 2013).

By the fifteenth century trade within the Southeast Asia archipelago had become highly profitable; the spices of the eastern Indonesian archipelago Moluccas - notably nutmeg, mace, and cloves - were in global demand. Intra-archipelago trade was at that time increasingly dominated by merchant-seafarers based in the transitional Muslim-ruled ports of Java's north coast, but mixed ethnic Eastern Archipelago sojourners, most notably those known as Bugis, were becoming a factor (L. Andaya 1993; Gaynor 2013). By the end of the fifteenth century, when the first Portuguese missions reached Asia, Melaka remained the major commercial hub of Asian trade. Early arriving Portuguese, whose home ports in the Atlantic Ocean were poor and provincial by Melaka's cosmopolitan standards, were awed by what they saw, and left impressive accounts of the bustling Melaka and its networked connections.

In the words of the early fifteenth century Portuguese scribe Tome Pires, Southeast Asia was "at the end of the monsoon, where you find what you want, and sometimes more than you are looking for" (Cortesao 1944: 228). When Europeans came to Southeast Asia in the early sixteenth century, they saw Melaka as more than a marketplace. It was a symbol of the wealth and luxury of Asia. They were eager to circumvent the monopoly of Venice on the priceless spice trade, and the great wealth and luxury available in this trade enticed them halfway around the world in their tiny, uncomfortable ships. Thus, when the Portuguese entered the Indian Ocean in the early 1500 s their objective was to seize Melaka, which they considered to be the then pivotal center of Asian trade. At the same time a fleet of ships based in north Java ports-of-trade were preparing a similar attack on Melaka, only to have the Portuguese do it first (Manguin 1993).

What the Portuguese did not understand was that Melaka was no more than an agreed upon marketplace intermediary for the commodities of other linked centers rather than an imperial authority. Thus, when the Portuguese seized Melaka many of the sedentary and migratory merchant communities responded by shifting their trade to other equally acceptable and mutually inter-changeable regional ports: Aceh, Johor, Java, Ayutthaya, Bago, Demak, Banjarmasin, and Hoi An among others. The inclusive Southeast Asia region remained prominent in sixteenth century Indian Ocean trade as a source of products, especially spices, and as an intermediary transit center strategically arbitrating exchange between Western and extended Eastern Indian Ocean maritime activity zones. 
International merchants who entered partnerships with the leaders of newly emerging regional polities capitalized on the benefits of alliances among rulers and merchants as in the past but at increased volume (Reid 1996; Lieberman 1997, 2003, 2009). This was similar to the way contemporary up-and-coming Western European monarchies (e.g., Tudor England and The Netherlands) were in partnership with evolving East India joint stock companies. Perhaps the greatest sixteenth century transition was due to the widespread use of gunpowder warfare that became a factor in limited regional competition in the previous century, notably in warfare between Dai Viet and China (Laichen 2006), but in response to Portuguese militancy Southeast Asian polities began to arm themselves and in some cases shifted their trade to strategic sites that were better suited for gunpowder warfare defense. Despite increased European aggression that was focal for establishing a regional monopoly, long established patterns of multi-centered trade and commodity transfers prevailed as regional authorities rapidly countered with their own gunpowder weaponry and employed European and Asian diaspora mercenaries (Laichen 2011, 2013). There was enhanced commercial maritime activity in the eastern Indonesian archipelago and Sulu Sea regions that had previously been peripheral to the mainline of Indian Ocean commerce.

In sum, the fluidity and continuity of 'borderless' maritime trade and cultural flows - most notably the regional embrace of Islam in insular Southeast Asia and variations of Theravada and Mahayana (Chan/Zen) Buddhism on the Southeast Asia mainland - that developed over the previous centuries was not significantly altered in the sixteenth century. Existing deeply rooted regional agencies were able to retain control of the major market forces and societal patterns that had long defined the extended eastern Indian Ocean region (Hall 2014a). As reported, while Melaka fell to the Portuguese in 1511, this did not significantly alter the existing eastern Indian Ocean trading system, but instead provided the opportunity for additional marketplaces to profit from the overall region's variety of products as consequent to enhanced international consumer demand. In the next century the Dutch would attempt to dominate Straits of Melaka and eastern Indonesian archipelago trade (Clulow 2014), but like the Portuguese earlier, they ultimately failed as the deeply rooted and diffused 'borderless' multi-dimensional eastern Indian Ocean cultural and commercial networks prevailed (Reid 2015).

\section{Bibliography}

Abu-Lughod, Janet. 1989. Before European Hegemony: The World System AD 12501350. New York: Oxford University Press.

Acri, Andrea, Helen Creese, and Arlo Griffiths (eds.). 2011. From Lanka Eastward. Leiden: KITLV.

Aelst, Arian Van. 1995. Majapahit Picis, the Currency of a 'Moneyless' Society 13001700. Bijdragen tot de Taal-, Land-, en Vokenkunde 151(3), 357-93. 
Andaya, Barbara Watson. 1993. To Live as Brothers, Southeast Sumatra in the Seventeenth and Eighteenth Centuries. Honolulu: University of Hawaii Press.

Andaya, Leonard Y. 1993. The World of Maluku: Eastern Indonesia in the Early Modern Period. Honolulu: University of Hawaii Press.

Andaya, Leonard Y. 2008. Leaves of the Same Tree: Trade and Ethnicity in the Straits of Melaka. Honolulu: University of Hawaii Press.

Asher, Catherine B. and Cynthia Talbot. 2006. India Before Europe. Cambridge: Cambridge University Press.

Aung Thwin, Michael. 1983. Pagan: The Origins of Modern Burma. Honolulu: University of Hawaii Press.

Aung Thwin, Michael and Kenneth R. Hall (eds.). 2011. New Perspectives on the History and Historiography of Southeast Asia, Continuing Explorations. London: Routledge.

Barnes, Ruth. 1989. Ikat Textiles of Lamalera: A Study of an Eastern Indonesian Weaving Tradition. Leiden: E. J. Brill.

Barnes, Ruth and Mary Hunt Kahlenberg (eds.). 2010. Five Centuries of Indonesian Textiles. Munich/New York: Demonico Books/Pestel Publishing.

Battuta, Ibn. 1929. Travels in Asia and Africa, 1325-1354 H. A. R. Gibb (trans.). London: Routledge \& Kegan Paul, Ltd.

Bielenstein, C. F. Hans. 2005. Trade and Diplomacy in the Chinese World 58 -1276. Leiden: E. J. Brill.

Blackburn, Anne M. 2015. Buddhist Connections in the Indian Ocean: Changes in Monastic Mobility, 1000-1500. Journal of the Economic and Social History of the Orient (JESHO) 58(3), 237-266.

Bronson, Bennet. 1992. Patterns of the Early Southeast Asian Metals Trade. In Glover (ed.). Ancient Trades and Cultural Contacts in Southeast Asia, pp. 63-114. Bangkok: White Lotus.

Brown, Roxanna M. 2008. The Ming Gap and Shipwreck Ceramics in Southeast Asia: Towards a Chronology of Thai Trade Ware. Bangkok: River Books.

Calo, Ambra. 2014. Trails of Bronze Drums Across Southeast Asia, Exchange Routes and Connected Cultural Spheres. Singapore: ISEAS.

Chaffee, John. 2006. Diasporic Identities in the Historical Development of the Maritime Muslim Communities of Song-Yuan China. JESHO 49(4), 395-420.

Chaffee, John. 2008. At the Intersection of Empire and World Trade: The Chinese Port City of Quanzhou (Zaitun), Eleventh-Fifteenth Centuries. In Kenneth R. Hall (ed.). Secondary Cities and Urban Networking in the Indian Ocean Realm, c. 1400-1800, pp. 99-122. Lanham, MD: Lexington Books.

Chang, Pin-tsun. 1991. The First Chinese Diaspora in Southeast Asia in the Fifteenth Century. In Roderich Ptak and Dietmar Rothermund (eds.). Emporia, Commodities and Entrepreneurs in Asian Maritime Trade, c. 1400-1750, pp. 13-28. Stuttgart: Steiner Verlag.

Chin, James K. 2013. Merchants, Envoys, Brokers and Pirates: Hokkien Connections in Pre-modern Maritime Asia. In Fujita Kayoko, Momoki Shiro, and Anthony Reid (eds.). Offshore Asia, Maritime Interactions in Eastern Asia Before Steamships, pp. 53-75. Singapore: ISEAS.

Clark, Hugh. 1991. Community, Trade, and Networks. Southern Fujian Province from the Third to the Thirteenth Centuries. Cambridge, MA: Harvard University Press.

Clark, Hugh. 2011. Secondary Ports and Their Cults: Religious Innovation in the Port System of Greater Quanzhou (Southern China) in the Tenth-Twelfth Centuries. In Hall, (ed.). The Growth of Non-Western Cities: Primary and Secondary Urban 
Networking, c. 900-1900, pp. 55-78. Lanham, MD: Lexington Press: Rowman and Littlefield.

Clark, Hugh. 2015. The Sinitic Encounter with the Southeast through the 1st Millennium. Honolulu: University of Hawaii Press.

Clulow, Anthony. 2014. The Company and the Shogun, The Dutch Encounter with Tokugawa Japan. New York: Columbia University Press.

Cooke, Nola; Li Tana and J. A. Anderson (eds.). 2013. The Tongking Gulf System Through History. Singapore: ISEAS.

Cortesao, A. 1944. A Translation of the Suma Oriental of Tome Pires, an Account of the East, from the Red Sea to Japan, Written in Malacca and India in 1512-1515. London: Hakluyt Society.

Ellen, Roy. 2003. On the Edge of the Banda Zone: Past and Present in the Social Organization of a Moluccan Trading Network. Honolulu: University of Hawaii Press.

Flecker, Michael. 2001. A Ninth-Century AD Arab or Indian Shipwreck in Indonesia: First Evidence for Direct Trade with China. World Archaeology 32(3), 335-354.

Flecker, Michael. 2002. The Archaeological Excavation of the Tenth-Century Intan Shipwreck. British Archaeological Reports International Series, 1047. Oxford: Archaeopress.

Frasch, Tilman. 1998. The Buddhist Network in the Bay of Bengal: Relations between Bodhgaya, Burma, and Sri Lanka, c. 300-1300. In Claude Guillot, Denys Lombard, and Roderich Ptak (eds.). From the Mediterranean to the China Sea: Miscellaneous Notes, pp. 69-92. Wiesbaden: Harrassowitz.

Gaynor, Jennifer L. 2013. Ages of Sail, Ocean Basins, and Southeast Asia. Journal of World History 24(2), 309-333.

Gayner, Jennifer L. 2016. Intertidal History in Island Southeast Asia. Ithaca, NY: Cornell University Press.

Gibb, H. R. 1957. (Ibn Battuta) Travels in Asia and Africa, 1325-1354. London: Dover.

Gil, Moshe. 2003. The Jewish Merchant in the Light of the Eleventh-Century Geniza Documents. JESHO 42(3), 249-72.

Gilman d'Arcy Paul, J. 1967. Notes on the Customs of Cambodia by Chou Ta-kuan. Bangkok: Social Science Association Press.

Gommans, Joseph J. and Jacques Leider (eds.). 2002. The Maritime Frontier of Burma. Leiden: KTLV.

Green, Gillian. 2000. Indic Impetus? Innovations in Textile Usage in Angkorian Period Cambodia. JESHO, 43(3), 277-313.

Green, Gillian. 2007. Angkor Vogue: Sculpted Evidence of Imported Luxury Textiles in the Courts of Kings and Temples. JESHO, 50(4), 424-451.

Gunder Frank, Andre. 1998. ReORIENT: Global Economy in the Asian Age. Berkeley: University of California Press.

Gunn, Geoffrey C. 2011. History without Borders: The Making of an Asian World Region, 1000-1800. Hong Kong: Hong Kong University Press.

Guy, John. 2001. Tamil Merchant Guilds and the Quanzhou Trade. In Angela Schottenhammer (ed.). The Emporium of the World: Maritime Quanzhou, 1000-1400, pp. 283-309. Leiden: E. J. Brill.

Hall, Kenneth R. 1996. The Southeast Asian Textile Trade, 1400-1800. JESHO 39(2), $87-135$.

Hall, Kenneth R. 2001. Unification of the Upstream and Downstream in Southeast Asia's First Islamic Polity: The Changing Sense of Community in the Fifteenth-Century Hikayat Raja-Raja Pasai. JESHO 42(2), 198-229. 
Hall, Kenneth R. 2010. Ports-of-Trade, Maritime Diasporas, and Networks of Trade and Cultural Integration in the Bay of Bengal Region of the Indian Ocean: c. 1000-1500. In Jos Gommans (ed.). Empires and Emporia: The Orient in World-Historical Space and Time, pp. 109-145. Leiden: E. J. Brill.

Hall, Kenneth R. 2010. Indonesia's Evolving International Relationships in the Ninth to Early Eleventh Centuries: Evidence from Contemporary Shipwrecks and Epigraphy. Indonesia 90 (October), 15-46.

Hall, Kenneth R. (ed.). 2011. The Growth of Non-Western Cities: Primary and Secondary Urban Networking, c. 900-1900. Lanham, MD: Lexington Press-Rowman and Littlefield.

Hall, Kenneth R. 2012. The 15th-Century Gujarat Cloth Trade with Southeast Asia's Indonesian Archipelago. In Lotika Varadarajan (ed.). Gujarat And The Sea, pp. 439466. Darshak Itihas Nidhi, Greater Noida (India).

Hall, Kenneth R. 2013. Cross-Cultural Commercial Competition on the Vietnam Coastline in the Fourteenth and Fifteenth Centuries. Journal of World History 24(1), 71105.

Hall, Kenneth R. 2014a. European Southeast Asia Encounters with Islamic Expansionism, circa 1500-1700: Comparative Case Studies of Banten, Ayutthaya, and Banjarmasin in the Wider Indian Ocean Context. Journal of World History 25(2/ 3), 229-262.

Hall, Kenneth R. 2014b. Networks of Trade, Polity, and Societal Integration in Chola-Era South India, c. 875-1279. Delhi: Primus Books.

Hall, Kenneth R. 2016. Networked Upstream-Downstream and Maritime 'Activity Zones' in 16th-19th Century Banjarmasin (Southeast Borneo). Paper presented at the Association for Asian Studies Annual Meeting, Seattle.

Hall, Kenneth R. Forthcoming 2017. Upstream and Downstream Networked 'Activity Zones' in 14th-16th Century Samudra-Pasai (Northeast Sumatra). The Asian Review of World Histories.

Henderson, J. 1999. Archaeological and Scientific Evidence for the Production of Early Islamic Glass in al Raqqa, Syria. Levant 31, 225-40.

Henderson, J. 2002. Tradition and experiment in First Millenium AD glass production the emergence of early Islamic glass technology in late antiquity. Accounts of Chemical Research 35(8), 594-602.

Heng, Derek. 2006. Export Commodity and Regional Currency: The Role of Chinese Copper Coins in the Melaka Straits, Tenth to Fourteenth Centuries. Journal of Southeast Asian Studies 37(2), 179-203.

Heng, Derek. 2008. Shipping, Customs Procedures and the Foreign Community: The Pingzhou ketan on Three Aspects of Guangzhou's Maritime Economy in the Late Eleventh Century AD. Journal of Song Yuan Studies 38(1), 1-38.

Heng, Derek. 2009. Sino-Malay Trade and Diplomacy from the Tenth through the Fourteenth Century. Athens, Ohio: Ohio University Press.

Ho, Enseng. 2006. Graves of Tarim: Genealogy and Mobility across the Indian Ocean. Berkeley: University of California Press.

Kathirithamby-Wells, J. and John Villiers (eds.). 1990. The Southeast Asian Port and Polity. Singapore: Singapore University Press.

Kayoko, Fujita, Momoki Shiro, and Anthony Reid (eds.). 2013. Offshore Asia, Maritime Interactions in Eastern Asia Before Steamships. Singapore: ISEAS.

Kozok, Uli, Thomas Hunter, Waruno Mahdi, and John Miksic. 2015. A 14th Century Malay Code of Laws, The Nitsarasamuccaya. Singapore: ISEAS. 
Krahl, Reginal. 2010. Chinese Ceramics in the Late Tang Dynasty, 45-73; Green Wares of Southern China, 185-99; White Wares of Northern China, 201-7; Tang Blue and White, 209-11. In Reginal Krahl, John Guy, J. Keith Wilson, and Julian Raby (eds.). Shipwrecked. Tang Treasures and Monsoon Winds. Singapore: Smithsonian Institution.

Krahl, Reginal, John Guy, J. Keith Wilson, and Julian Raby (eds.). 2010. Shipwrecked. Tang Treasures and Monsoon Winds. Singapore: Smithsonian Institution.

Kulke, Hermann. 1993. Kings and Cults: State Formation and Legitimation in India and Southeast Asia. New Delhi: Manohar.

Kulke, Hermann. 1999. Rivalry and Competition in the Bay of Bengal in the Eleventh Century and Its Bearing on Indian Ocean Studies. In Om Prakash and Denys Lombard (eds.). Commerce and Culture in the Bay of Bengal, pp. 17-35. New Delhi: Manohar

Kulke, Hermann, K. Kesavapany, and Vijay Sakhuja (eds.). 2009. Nagapattinam to Suvarnadwipa, References on the Chola Naval Expeditions to South-East Asia. Singapore: ISEAS.

Laichen, Sun. 2003. Chinese Military Technology Transfers and the Emergence of Northern Mainland Southeast Asia, c. 1390-1527. Journal of Southeast Asian Studies 34(3), 495-517.

Laichen, Sun. 2006. Chinese Gunpowder Technology and Dai Viet: c. 1390-1497. In Nhung Tuyet Tran and Anthony Reid (eds.). Viet Nam: Borderless Histories, pp. 72-120. Madison: University of Wisconsin Press.

Laichen, Sun. 2011. Chinese-style Gunpowder Weapons in Southeast Asia. In Aung Thwin and Hall (eds.). New Perspectives on the History and Historiography of Southeast Asia, Continuing Explorations, pp. 75-111. London: Routledge.

Laichen, Sun. 2013. Saltpetre Trade and Warfare in Early Modern Asia. In Kayoko et al. (eds.). Offshore Asia, 130-184.

Lambourn, Elizabeth. 2003. From Cambay to Samudera-Pasai and Gresik - The Export of Gujarat Grave Memorials to Sumatra and Java in the Fifteenth Century. Indonesian and Malay World 31(July), 221-289.

Lambourn, Elizabeth. 2008. Tombstones, Texts, and Typologies — Seeing Sources for the Early History of Islam in Southeast Asia. JESHO 52(2), 252-286.

Lambourn, Elizabeth. 2011. Khutba and Muslim Networks in the Indian Ocean: Tamurid and Ottoman Engagements. In Hall (ed.). The Growth of Non-Western Cities, 127154.

Lammerts, D. Christian (ed.). 2014. Buddhist Dynamics in Premodern and Early Modern Southeast Asia. Singapore: ISEAS.

Lieberman, Victor. 1997. Transcending East-West Dichotomies: State and Culture Formation in Six Ostensibly Disparate Areas. Modern Asian Studies 31, 463-546.

Lieberman, Victor. 2003. Strange Parallels: Southeast Asia in Global Context: c. 8001830, Vol. I, Integration on the Mainland. Cambridge: Cambridge University Press.

Lieberman, Victor. 2009. Strange Parallels, Vol. 2, Mainland Mirrors: Europe, Japan, China, South Asia, and the Islands. Cambridge: Cambridge University Press.

Lieberman, Victor. 2010. Maritime influences in Southeast Asia, c. 900-1300: Some further Thoughts. Journal of Southeast Asian Studies 41(3), 529-539.

Lieberman, Victor. 2011. Charter State Collapse in Southeast Asia, ca. 1250-1400, as a Problem in Regional and World History. American Historical Review 116(4), 937963.

Mair, Victor and Liam Kelley (eds.). 2015. Imperial China and Its Southern Neighbours. Singapore: ISEAS. 
Milner, A. C. 1982. Kerajaan: Malay Political Culture on the Eve of Colonial Rule. Tucson, AZ: Association for Asian Studies.

Manguin, Pierre-Yves. 1991. The Merchant and the King: Political Myths of Southeast Asian Coastal Polities. Indonesia 52(October), 41-54.

Manguin, Pierre-Yves. 1993. Trading Ships of the South China Sea: Shipping Techniques and Their Role in the History of the Development of Asian Trade Networks. JESHO 36 (3), 253-280.

Manguin, Pierre-Yves. 2002. The Amorphous Nature of Coastal Polities in Insular Southeast Asia: Restricted Centers, Extended Peripheries. Moussons 4, 73-99.

Manguin, Pierre. 2016. Shipmasters of Insular Southeast Asia: Seafarers and Entrepreneurs. Paper presented at the Association for Asian Studies Annual Meeting (Seattle).

Meilink-Roelofsz, M. A. P. 1955. Asian Trade and European Influence in the Indonesian Archipelago between 1500 and about 1630. The Hague: Martinus Nijhoff.

Miksic, John (ed.). 2009. Southeast Asian Ceramics, New Light on Old Pottery. Singapore: Southeast Asian Ceramic Society.

Miksic, John. 2013. Singapore and the Silk Road of the Sea. Singapore: National University of Singapore Press.

Morillo, Stephen. 2011. Cities, Networks, and Cultures of Knowledge: A Global Overview. In Hall (ed.). The Growth of Non-Western Cities, 1-20.

Mukherjee, Rila (ed.). 2011. Pelagic Passageways, The Northern Bay of Bengal Before Colonialism. Delhi: Primus Books.

Mukherjee, Rila (ed.). 2014. Vanguards of Globalization: Port Cities from the Classical to the Modern, Delhi: Primus Books.

Park, Hyunhee. 2011. Port-City Networking in the Indian Ocean Commercial System Represented in Geographic and Cartographic Works in China and the Islamic West from 750 to 1500. In Hall, (ed.)., The Growth of Non-Western Cities, 21-54.

Ptak, Roderich. 1992. The Northern Route to the Spice Islands: South China Sea-Sulu Zone-North Moluccas (Fourteenth to Early Sixteenth Century). Archipel 43(1), $27-56$.

Ptak, Roderich. 1993. China and the Trade in Cloves, circa 960-1435. Journal of the American Oriental Society 113(1), 1-13.

Ptak, Roderich. 1998a. From Quanzhou to the Sulu Zone and Beyond: Questions Related to the Early Fourteenth Century. Journal of Southeast Asian Studies 29(2), 269-94.

Ptak, Roderick. 1998b. Possible Chinese Reference to the Barus Area (Tang to Ming). In Claude Guillot (ed.). Historie de Barus. Le Site de Lobu Tua, pp. 119-147. Paris: Association Archipel.

Ray, Himanshu P. 1994. Winds of Change: Buddhism and the Maritime Links of Early Southeast Asia. Delhi: Oxford University Press.

Reid, Anthony (ed.). 1996. Sojourners and Settlers: Histories of Southeast Asia and the Chinese. New South Wales, Australia: Allen and Unwin.

Reid, Anthony. 2000. The Culture of Malay Speaking City States of the Fifteen and Sixteen Centuries. In Mogens Herman Hansen (ed.). A Comparative Study of Thirty City-State Cultures, pp. 417-429. Copenhagen: The Royal Danish Academy of Sciences and Letters.

Reid, Anthony. 2015. A History of Southeast Asia, Critical Crossroads. West Sussex (UK): Wiley-Blackwell.

Robson, Stuart O. 1995. Desarwarnana (Negarakertagama) by Mpu Prapanca. Leiden: KTLV. 
Salmon, Claudine. 2002. Srivijaya la Chine et les marchands chinois (Xe-XIIe s.) Quelques reflexions sur la societe de l'empire sumatranais. Archipel 63, 57-78.

Schottenhammer, A. and R. Ptak (eds.). 2006. The Perception of Maritime Space in Traditional Chinese Sources. Wiesbaden: Harrassowitz.

Sen, Tansen. 2003. Buddhism, Diplomacy, and Trade: The Realignment of Sino-Indian Relations, 600-1400. Honolulu: University of Hawaii Press,

Sen, Tansen. 2014. Maritime Southeast Asia between South Asia and China to the Sixteenth Century. TRaNS 2(1), 44-55.

Shiro, Momoki. 1998. Dai Viet and the South China Sea Trade from the Tenth to the Fifteenth Century. Crossroads 12(1), 1-34.

Shiro, Momoki and Hasuda Takashi. 2013. The Periodization of Southeast Asian History, in Comparison with that of Northeast Asia. In Kayoko, et al. (eds.), 16-52.

Sims-Williams, Nicholas. 1994. The Sogdian Merchants in China and India. In Alfredo Cadonna and Lionello Lanciotti (eds.). Cina e Iran: Da Alessandro Magno alla Dinastia Tang, 45-67. Florence, Firenze: Leo S. Olschiki Editore.

So, Billy Kee-Long. 1998. Dissolving Hegemony or Changing Trade Pattern: Srivijaya Images in the Chinese Sources of the Twelfth and Thirteenth Centuries. Journal of Southeast Asian Studies 29(2), 295-308.

So, Billy Kee-Long. 2000. Prosperity, Region, and Institutions in Maritime China: The South Fukien Pattern, 946-1368. Boston: Harvard University Press.

Subrahmanyam, Sanjay. 1999. Persianization and Mercantilism: Two Themes in Bay of Bengal History. In Om Prakash and Denys Lombard (eds.). Commerce and Culture in the Bay of Bengal, 1500-1800, pp. 47-85. New Delhi: Monohar.

Tan, Hiedi (ed.). 2012. Marine Archaeology in Southeast Asia, Innovation and Adaptation. Singapore: Asian Civilizations Museum.

Tana, Li. 2006. A View from the Sea: Perspectives on the Northern and Central Vietnamese Coasts. Journal of Southeast Asian Studies 37(1), 83-102.

Thomaz, Luis Filipe Reis. 1993. The Malay Sultanate of Melaka. In Anthony Reid (ed.). Southeast Asia in the Early Modern Era, pp. 69-90. Ithaca, NY: Cornell University Press.

Vickery, Michael. 2003. Funan Reviewed: Deconstructing the Ancients. Bulletin de l'Ecole Française d'Extrême-Orient, 90-143.

Wade, Geoff. 2005. The Zheng He Voyages: A Reassessment. Journal of the Malaysian Branch of the Royal Asiatic Society 78(1), 3-58.

Wade, Geoff. 2009. An Early Age of Commerce in Southeast Asia, 900-1300 CE. Journal of Southeast Asian Studies 40(2), 221-265.

Wade, Geoff. 2010. Early Muslim Expansion in South-East Asia, Eighth to Fifteenth Centuries. In David O Morgan and Anthony Reid (eds.). The New Cambridge History of Islam Volume 3: The Eastern Islamic World, Eleventh to Eighteenth Centuries, 366-408. Cambridge: Cambridge University Press.

Wade, Geoff and Sun Laichen (eds.). 2010. Southeast Asia in the Fifteenth Century: The China Factor. Singapore: National University of Singapore Press.

Wade, Geoff. 2013. An Asian Commercial Ecumene, 900-1300. In Kayoko, et al. (eds.), 76-111.

Wade, Geoff (ed.). 2015. Asian Expansions: the Historical Experiences of Polity Expansion in Asia. London: Routledge.

Wade, Geoff (ed.). 2016. China and Southeast Asia: Historical Interactions. Abingdon (UK): Routledge.

Wake, Christopher. 1967. Malacca's Early Kings and the Reception of Islam. Journal of Southeast Asian Studies 5(2), 104-28. 
Wheatley, Paul. 1983. Nagara and Commandery: Origins of Southeast Asian Urban Traditions. Chicago: University of Chicago Department of Geography.

Wheeler, Charles. 2011. Maritime Subversions and Socio-Political Formations in Vietnamese History: A Look from the Marginal Center (mien Trung). In Aung Thwin and Hall (eds.). New Perspectives, 141-156.

Winstedt, Richard and P. E. Josselin De Jong. 1956. The Maritime Laws of Malacca. Journal of the Malayan Branch of the Royal Asiatic Society. 29(3), 22-59.

Whitmore, John K. 2011. Why Did Le Van Thinh Revolt? Buddhism and Political Integration in Early Twelfth-Century Dai Viet. In Hall (ed.), The Growth of NonWestern Cities, 107-126.

Whitmore, John K. 2014. Ngo (Chinese) Communities and Montane-Littoral Conflict in Dai Viet, ca. 1400-1600. Asia Major 26(2), 2014.

Whitmore, John K. 2017a. The Fall of Vijaya in 1471, Decline or Competition? Campa in the Fifteenth Century. In A. Griffiths, A. Hardy, and G. Wade (eds.). Campa: Territories and Networks of a Southeast Asian Kingdom. Paris: École Francaise d'Extrême Orient.

Whitmore, John. K. 2017b. India and China on the Eastern Seaboard of Mainland Southeast Asia: Links and Changes, 1100-1600. In A. Dallapiccola and A. Verghese (eds.). Cultural Dialogues between India and Southeast Asia from the Seventh to the Sixteenth Centuries. Mumbai: KR Cama Institute.

Wisseman Christie, Jan. 1992. Trade and Settlement in Early Java: Integrating the Epigraphic and Archaeological Data. In Glover, Ian, et al. (eds.). Early Metallurgy, Trade, and Urban Centres, 188-92.

Wisseman Christie, Jan. 1993. Texts and Textiles in Medieval Java. Bulletin de l'Ecole Francaise d'Extreme Orient 80(1), 181-211.

Wisseman Christie, Jan. 1996. Money and Its Uses in the Javanese States of the Ninth to Fifteenth Centuries AD. JESHO 39(93), 243-86.

Wisseman Christie, Jan. 1998. Javanese Markets and the Asian Sea Trade Boom of the Tenth to Thirteenth Centuries AD. JESHO 41(3), 364-78.

Wisseman Christie, Jan. 1999. Asian Trade between the Tenth and the Thirteenth Centuries and Its Impact on the States of Java and Bali. In Himanshu Ray (ed.). Archaeology of Seafaring, The Indian Ocean in the Ancient Period, pp. 221-70. Delhi: Pragati Publications.

Wolters, O. W. 1967. Early Indonesian Commerce: A Study of the Origins of Srivijaya. Ithaca, NY: Cornell University Press.

Wolters, O. W. 1970. The Fall of Srivijaya in Malay History. Ithaca, New York: Cornell University Press.

Wolters, O. W. 1979. Studying Srivijaya. Journal of the Malaysian Branch of the Royal Asiatic Society 52(2), 1-52.

Wolters, O. W. 1982 (revised 1999). History, Culture, and Region in Southeast Asia Perspectives. Ithaca, NY: Cornell University Press.

Yang, Bin. 2004. Horses, Silver, and Cowries: Yunnan in Global Perspective. Journal of World History 15(3), 281-322.

Yang, Bin. 2011. The Rise and Fall of Cowrie Shells: The Asian Story. Journal of World History 22(1), 1-25.

Yoshinobu, Shida. 1970. Commerce and Society in Sung China. Ann Arbor: University of Michigan Center for Chinese Studies. 